\title{
Habitat as a factor involved in the physiological response to environmental anaerobiosis of White Sea Mytilus edulis
}

\author{
A. A. Sukhotin ${ }^{1}$, H.-O. Pörtner ${ }^{2, *}$ \\ ${ }^{1}$ White Sea Biological Station, Zoological Institute of Russian Academy of Sciences, Universitetskaya nab. 1, \\ 199034 St. Petersburg, Russia \\ ${ }^{2}$ Alfred-Wegener-Institut für Polar und Meeresiorschung, Biologie I/Ökophysiologie, Columbusstraße, \\ D-27568 Bremerhaven, Germany
}

\begin{abstract}
The ability of blue mussels Mytilus edulis $\mathrm{L}$. to withstand severe environmental hypoxia was studied in mussels from an intertidal population and from a suspended cultured settlement. Specimens were exposed to air for $60 \mathrm{~h}$ at $+10^{\circ} \mathrm{C}$. Tissues were analysed for the amount of anaerobic metabolic end products, adenylates, phosphagen, and inorganic phosphate, and for changes in intracellular $\mathrm{pH}\left(\mathrm{pH}_{\mathrm{i}}\right)$. Proton balance and Gibb's free energy of ATP hydrolysis were calculated. Under the experimental conditions applied succinate appeared to be the only anaerobic end product. Under control conditions $\mathrm{pH}_{1}$ measured using the homogenate technique ranged between 6.78 and 6.85 in both groups. Very small decreases in $\mathrm{pH}_{i}$ were observed after air exposure. Rapid breakdown of ATP and phosphoL-arginine (PLA) was accompanied by the accumulation of inorganic phosphate, free AMP and ADP. The Gibb's free energy change of ATP hydrolysis decreased from about -57 to $-50 \mathrm{~kJ} \mathrm{~mol}{ }^{-1}$, showing the depletion of energy reserves in the tissues. The calculated ATP turnover rate was higher in intertidal mussels. It is concluded that mussels from the intertidal zone demonstrate lower abilities for metabolic depression under the conditions of air exposure than cultured (sublittoral) ones. The latter are characterised by higher initial PLA content. These differences may be related to a difference in mitochondrial density depending on the habitat.
\end{abstract}

KEY WORDS: Mytilus edulis - Anaerobiosis - Intracellular pH - Metabolic rate Succinate - Adenylates . Phosphagen Inorganic phosphate Blue mussel Habitat dependence - White Sea

\section{INTRODUCTION}

Blue mussels Mytilus edulis L. belong to a species complex characterised by high ecological plasticity. They inhabit the temperate and boreal zones of the northern hemisphere with different temperature and salinity regimes (for review see Seed \& Suchanek 1992). Besides that, the species complex colonises both subtidal and intertidal zones, forming dense settlements on tidal flats, which are exposed to air for up to $55-75 \%$ of the time in a tidal cycle (Baird 1966, Seed 1969). Mussels living in biotopes with very different ecological conditions display physiological differences.

'Addressee for correspondence.

E-mail: hpoertner@awi-bremerhaven.de
Some of these differences, such as growth rate (Dickie et al. 1984, Sukhotin \& Maximovich 1994), respiration rate (Okumus \& Stirling 1994) and clearance rate (Okumus \& Stirling 1994, Labarta et al. 1997), are completely determined by environmental parameters and disappear after placing the mussels in equal life conditions. Others, such as assimilation efficiency (Labarta et al. 1997), mortality rate (Dickie et al 1984, Mallet et al. 1990), energy partitioning (Rodhouse et al. 1984) and ammonia excretion (Okumus \& Stirling 1994), are maintained for prolonged periods suggesting the presence of genetic differences between the populations or an 'ecological memory' of the individuals with respect to pre-experimental conditions. Among them is the difference between mussels in their response to air exposure. It was shown by many authors that initial acclima- 
tisation to subtidal or intertical conditions changes some parameters of metabolism in bivalves during anoxia. Thus, mussels from low and high tidal levels showed a difference in 'oxygen debt' after air exposure (Moon \& Pritchard 1970, de Vooys \& de Zwaan 1978); subtidal and intertidal $M$. edulis during and after exposure to air were characterised by differences in the activity of pyruvate kinase (Holwerda et al. 1984) and in mortality (Wijsman 1976, Demers \& Guderley 1994). Total heat dissipation in intertidal mussels during air exposure and especially during recovery tended to be greater than in subtidal ones (Shick et al. 1986). It has been reported that short-term intertidal acclimatisation favours the accumulation of opines and decreases the use of the succinate pathway in $M$. edulis (Demers \& Guderley 1994). However, the data remain controversial. Acclimatization of $M$. galloprovincialis to the intertidal regime leads to an increase of succinate accumulation during environmental anaerobiosis (de Vooys 1979), while in $M$. edulis the opposite appears to be the case (Demers \& Guderley 1994). No differences were observed in the adenylate energy charge in oysters Crassostrea gigas from different tidal levels (Moal et al. 1989). Therefore, the main goal of the present work was to investigate whether there are differences in the energetics of mussels from littoral and suspended culture populations under normal conditions as well as during exposure to air.

\section{MATERIAL AND METHODS}

Mussels. Blue mussels Mytilus edulis L. Were collected in late September 1996 from 2 different sites near Cape Kartesh (Kandalaksha Bay, White Sea; $66^{\circ} 20.230^{\prime} \mathrm{N}, 33^{\circ} 38.972^{\prime} \mathrm{E}$ ). The region is characterised by a prolonged and cold winter season and a short, relatively warm summer. Ice covers the sea from December to early May. The warmest summer month is August with a mean temperature in the surface water layer of $+13.8^{\circ} \mathrm{C}$. Extreme water temperatures are $-1.5^{\circ} \mathrm{C}$ and $+19.3^{\circ} \mathrm{C}$ (Babkov 1982 ); therefore, seasonal changes cover more than $20^{\circ} \mathrm{C}$. In contrast, air exposed mussels in the intertidal zone experience heating with body temperatures of up to $38^{\circ} \mathrm{C}$ (Sukhotin \& Berger unpubl. data).

Tides in the region are regular with an amplitude of about $2 \mathrm{~m}$. Salinity in the surface waters ranges between 24 and $26 \%$ with a large decrease in AprilMay to $15 \%$. In some years it may decline to near $0 \%$ (Babkov 1982, Babkov \& Lukanin 1985). Investigated mussel populations were situated $2 \mathrm{~km}$ apart from each other. The intertidal settlement is a mussel bed between -0.2 and $+1.2 \mathrm{~m}$ above $0 \mathrm{~m}$ tidal level and is characterised by a density of about 10000 ind. $\mathrm{m}^{-2}$.
Four to 6 yr old mussels comprise more than $60 \%$ of the total number. Cultured mussels grow on $3 \mathrm{~m}$ ropes hanging from the rafts of a small mussel aquaculture farm. Mussel density was about 4500 ind. $\mathrm{m}^{-1}$ of rope. Two year old mussels represented $80 \%$ of the population. Mussels from both investigated locations live at the same mean temperatures. However, intertidal mussels are subjected to wider daily temperature fluctuations and are regularly exposed to air, while cultured mussels experience conditions supporting larger growth rates and never encounter air exposure.

Mussels were sampled from the littoral settlement at the level of $+0.7 \mathrm{~m}$, where the emersion period comprises about $20 \%$ of the tidal cycle. The other sample was taken from suspended substrates of a mussel aquaculture farm at $1 \mathrm{~m}$ depth. After collection mussels were kept in aquaria for $2 \mathrm{~d}$. Then they were transported to the Alfred-Wegener Institute (Bremerhaven, Germany) and placed in aquaria containing filtered recirculated natural sea water. Temperature was maintained at $+10^{\circ} \mathrm{C}$, salinity was 22 to $24 \%$. No food was added.

Wet tissue weight of mussels varied between 0.6 and $0.8 \mathrm{~g}$ with mean values of $0.73 \pm 0.02 \mathrm{~g}(\mathrm{SE}, \mathrm{n}=33$ ) for aquaculture and of $0.64 \pm 0.03 \mathrm{~g}$ ( $\mathrm{SE}, \mathrm{n}=35$ ) for littoral mussels. Age of the mussels was determined by counting and measuring the rings of winter growth delays on the shells. All cultured mussels were 2 yr old while littoral ones varied between 5 and 10 yr of age.

Experimental design. After $2 \mathrm{wk}$ of acclimatization in the laboratory 20 mussels from each habitat were exposed to air for $60 \mathrm{~h}$. Air exposure was performed at the same temperature $\left(+10^{\circ} \mathrm{C}\right)$. Other mussels (controls) remained immersed. It is well known that during exposure to air Mytilus edulis can maintain both aerobic and anaerobic metabolism using atmospheric oxygen due to shell gaping (Coleman 1973, Widdows et al. 1979, Shick et al. 1986). To avoid differences in gaping and to prevent the diffusion of oxygen into the mantle fluid and the desiccation of tissues, exposed mussels were kept tightly closed by ribbon bands. After air exposure, control and exposed mussels were quickly opened and all tissues were withdrawn from the shells, weighed, and frozen by freeze-clamping in liquid nitrogen (Wollenberger et al. 1960).

Analyses. All tissues of the mussel body were pooled for further analysis. Intracellular $\mathrm{pH}\left(\mathrm{pH}_{\mathrm{j}}\right)$ was determined using the homogenate technique (Pörtner et al. 1990). Samples were powdered in liquid nitrogen and then resuspended in ice-cold medium containing $160 \mathrm{mM} \mathrm{KF}$ and $1 \mathrm{mM}$ nitrilotriacetic acid. $\mathrm{pH}$ of the medium was 6.5. After centrifugation $\mathrm{pH}$ of the supernatant was determined with a capillary electrode (Radiometer, Copenhagen E5021) thermostatted to the temperature of the experiment $\left(+10^{\circ} \mathrm{C}\right)$ 
Anaerobic end products, adenylates, phosphagens and inorganic phosphate were determined in perchloric acid extracts. Weighed tissue samples ground under liquid nitrogen were added to 3 times the volume of ice-cold $0.6 \mathrm{M}$ perchloric acid. After homogenisation and further centrifugation the $\mathrm{pH}$ of the extract was adjusted to $7.0-7.5$ by use of $5 \mathrm{M} \mathrm{KOH}$. After final centrifugation the supernatant was stored at $-80^{\circ} \mathrm{C}$.

Alanopine and strombine were analysed by ion exclusion chromatography using an HPLC system as described in Sommer et al. (1997). Succinate, acetate and propionate were measured according to a method described in Hardewig et al. (1991) and Sommer et al. (1997). Concentrations of AMP, ADP and ATP were measured by HPLC according to the method described by Fischer (1995). The amounts of inorganic phosphate $\left(\mathrm{P}_{1}\right), \mathrm{L}$-arginine (LA) and phospho-L-arginine (PLA) in extracts were determined spectrophotometrically using enzymatic tests according to Grieshaber et al. (1978) and Pörtner (1990)

Calculations and statistics. The ratio of PLA to PLA+LA levels ( $R_{\text {PLA }}$ ) was calculated as [PLA]/[LA]+ [PLA]. Adenylate energy charge (AEC) was estimated according to Atkinson (1968). The levels of free AMP and AMP as well as values of Gibb's free energy change of ATP hydrolysis were calculated in accordance with the method described in Pörtner et al. (1996). Free $\mathrm{Mg}^{2+}$ concentration was assumed to be $1 \mathrm{mmol} \mathrm{l}^{-1}$.

Metabolic proton production $\left(\Delta \mathrm{H}^{+}\right.$met $)$was estimated based on the differences in metabolite concentrations between exposed and control mussels, assuming that accumulation of $1 \mathrm{~mol}$ of succinate is accompanied by the release of $2 \mathrm{~mol}$ of protons (Pörtner 1987a), and that ATP hydrolysis does not add protons at the obtained $\mathrm{pH}_{1}$ values (Pörtner 1987a). Influence of PLA breakdown on proton balance was accounted for by estimating proton quantities bound by the phosphate buffer. The fraction of protonated phosphate $(F)$ was calculated using the equation $F=1 /\left(10^{\mathrm{pH}-\mathrm{pKa}}+1\right)$, assuming that $\mathrm{pKa}\left(10^{\circ} \mathrm{C}\right)=6.836$. The non-respiratory proton production $\left(\Delta \mathrm{H}^{+}{ }_{\text {non-resp }}\right)$ was calculated as: $\Delta \mathrm{H}^{+}{ }_{\text {non-resp }}=$ $-\left|\beta_{N B}\right| \cdot \Delta \mathrm{pH}_{\mathrm{i}}-\Delta \mathrm{Bic}\left(\mu \mathrm{mol} \mathrm{g}^{-1}\right.$ wet wt), where $\beta_{\mathrm{NB}}$ is the non-bicarbonate tissue buffer value, and Bic is bicarbonate concentration (Pörtner 1987b). $\beta_{\mathrm{NB}}$ was

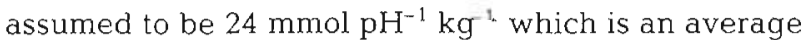
value for muscle and non-muscle tissues in 2 bivalve molluscs (Eberlee \& Storey 1984) possibly somewhat overestimated for methodological reasons (Pörtner 1990). We did not measure changes in bicarbonate concentrations; therefore, $\Delta B$ ic values were neglected, thus giving only a rough estimate of the non-respiratory proton production. However, bicarbonate levels at the $\mathrm{pH}_{\mathrm{i}}$ measured are small and will not greatly influence the analysis 2-way ANOVA was used for analysing the effect of the factors habitat and exposure versus controls. Post hoc comparisons were made by Tukey's HSD Test for unequal $N$. All parameters, except $P_{i}$, were weight independent. In the ANOVA of $P_{1}$ levels tissue weight was included as a covariate. Calculation of the parameters of linear regressions was performed according to a standard algorithm (Glotov et al. 1982). Correlations were calculated using Spearman's non-parametric correlation coefficients. All calculations were performed with the package Statistica for Windows, Release 4.3 (StatSoft, Inc.).

\section{RESULTS}

\section{Intracellular $\mathrm{pH}$}

$\mathrm{pH}_{\mathrm{i}}$ values in White Sea mussels under normoxic conditions varied between 6.66 and 6.96 with means equal to $6.85 \pm 0.01$ for cultured and $6.78 \pm 0.02$ for littoral specimens. ANOVA showed a significant $(\mathrm{p}<$ 0.001 ) influence of exposure and habitat on the $\mathrm{pH}_{1}$ of the mussels. Air exposure caused a reduction in $\mathrm{pH}_{1}$ in both groups of mussels (Fig. 1a). The $\mathrm{pH}$ change was larger in cultured mussels, and was characterised by higher initial $\mathrm{pH}_{1}$ values. Cultured mussels had a higher $\mathrm{pH}_{1}$ after anoxia as well, but this difference was not statistically significant.

\section{Anaerobic end products}

Concentrations of alanopine, strombine, acetate and propionate in the tissues of White Sea mussels were below limits of detection in both control and air exposed groups. Succinate appeared to be the only significant end product. The effects of habitat and air exposure as well as of the combined factors on succinate concentration were highly significant (ANOVA, $p<0.001$ ). In control groups cultured and littoral mussels did not differ significantly in the concentration of succinate; nonetheless, mean levels were 2 times less in cultured than in littoral specimens. After exposure to air considerable succinate accumulation was observed in both groups, and this increase was more pronounced by a factor of 1.5 in littoral specimens (Fig. 1b).

\section{Inorganic phosphate}

The concentration of $P_{i}$ in mussels was significantly influenced by both factors-exposure (ANOVA, p < 0.001 ) and habitat (ANOVA, p $<0.02$ ) - but not by 

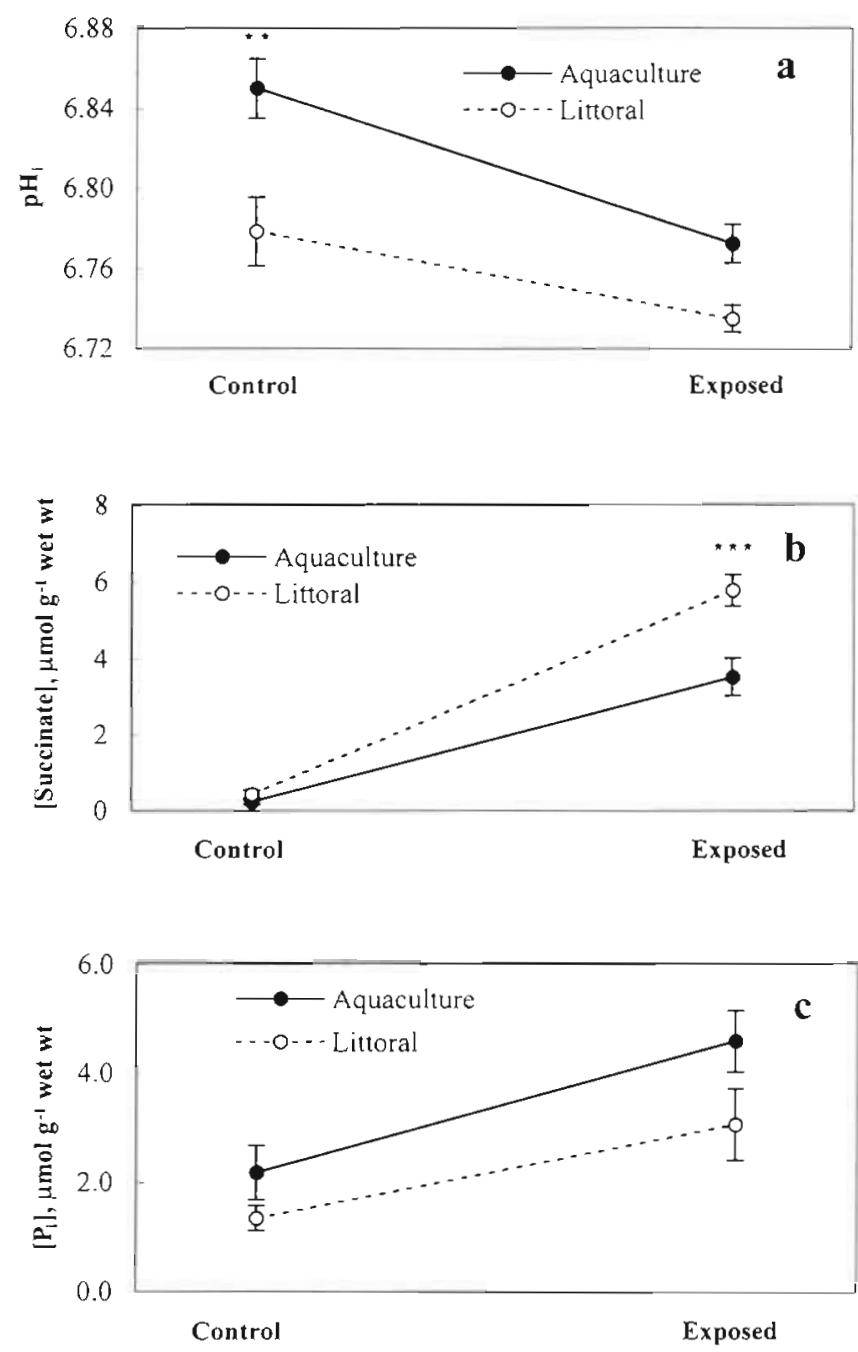

Fig. 1. (a) Intracellular $\mathrm{pH}\left(\mathrm{pH}_{1}\right)$; (b) succinate concentrations and $(c)$ inorganic phosphate concentrations $\left(\mathrm{P}_{\mathrm{j}}\right)$ in cultured and littoral mussels. Vertical bars represent standard errors. Difference of mean values for cultured and littoral specimens at $p=0.05, \cdots p=0.01$ and $\cdots p=0.001$ levels

their combination. This means that the effect of exposure did not differ in littoral and cultured mussels. Absolute values under normoxia were between 1.5 and $2.5 \mu \mathrm{mol} \mathrm{g}^{-1}$ wet wt. Air exposure for $60 \mathrm{~h} \mathrm{led} \mathrm{to} \mathrm{a}$ 2 -fold increase in $P_{1}$ concentrations in both groups of mussels. $P_{i}$ levels were always lower in the littoral group (Fig. 1c)

\section{Phosphagen}

2 -way ANOVA showed the significant ( $p<0.001)$ influence of both investigated factors, i.e. exposure and habitat, on the concentrations of LA and PLA as well as on the ratio of PLA content over the sum of PLA and LA concentrations.
The initial concentrations of PLA in cultured mussels were more than 2 times higher than in littoral mussels (Fig. 2a). Air exposure caused a considerable depletion of PLA due to its transphosphorylation to ADP. Final amounts of PLA were similar in mussels from both investigated habitats. Thus, the decrease of PLA during the emersion was by $3.07 \mu \mathrm{mol} \mathrm{g}^{-1}$ wet wt in cultured and by $1.28 \mu \mathrm{mol} \mathrm{g}^{-1}$ wet wt in littoral mussels.

The degradation of PLA was correlated with the release and accumulation of LA in mussel tissues. LA
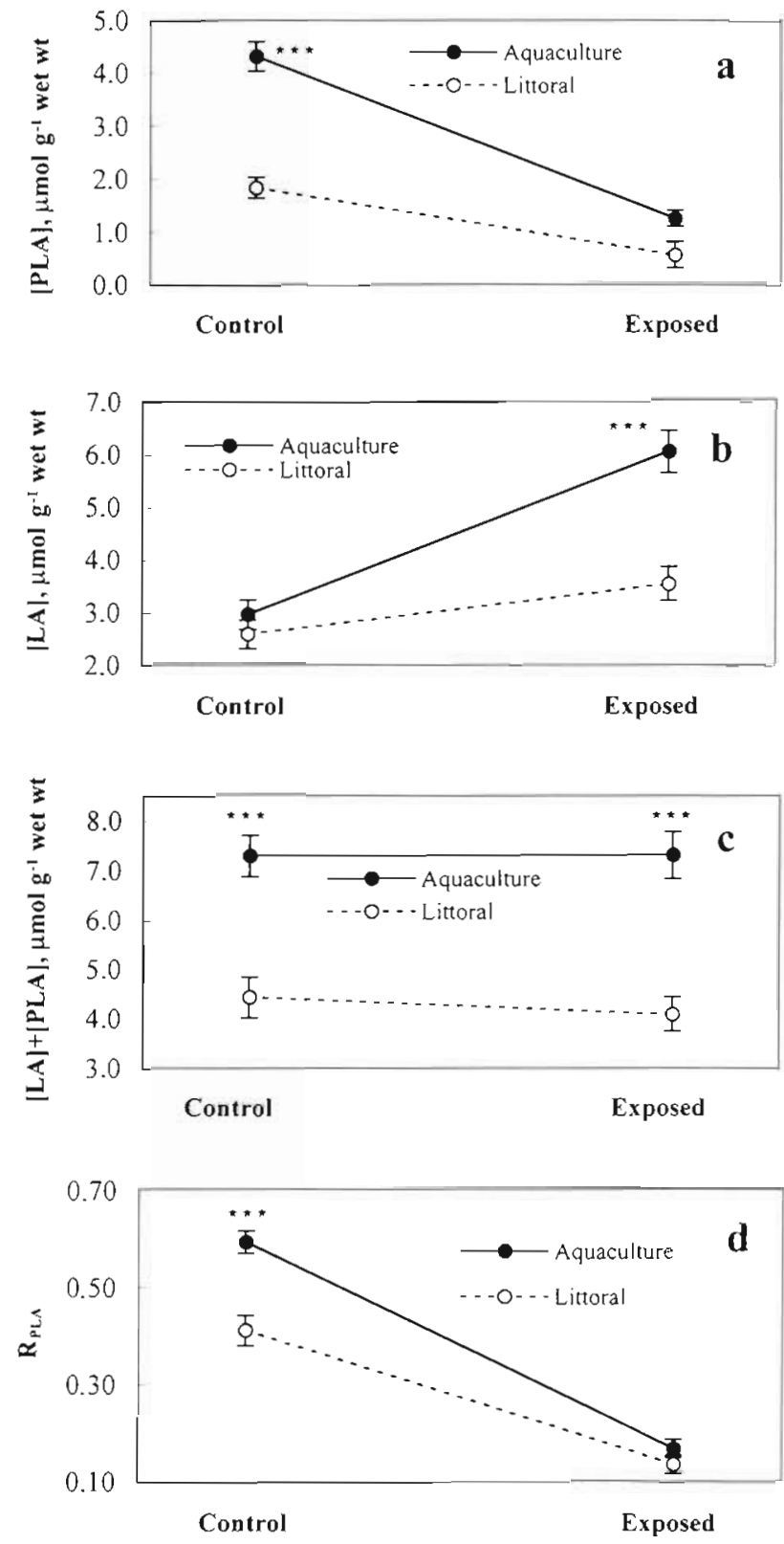

Fig. 2. (a) Concentrations of phospho-L-arginine (PLA), (b) Larginine (LA), (c) the whole phosphagen/aphosphagen pool, and $(d)$ relative amount of PLA $\left(R_{P L A}\right)$ in cultured and littoral. mussels. For further information see Fig. 1 

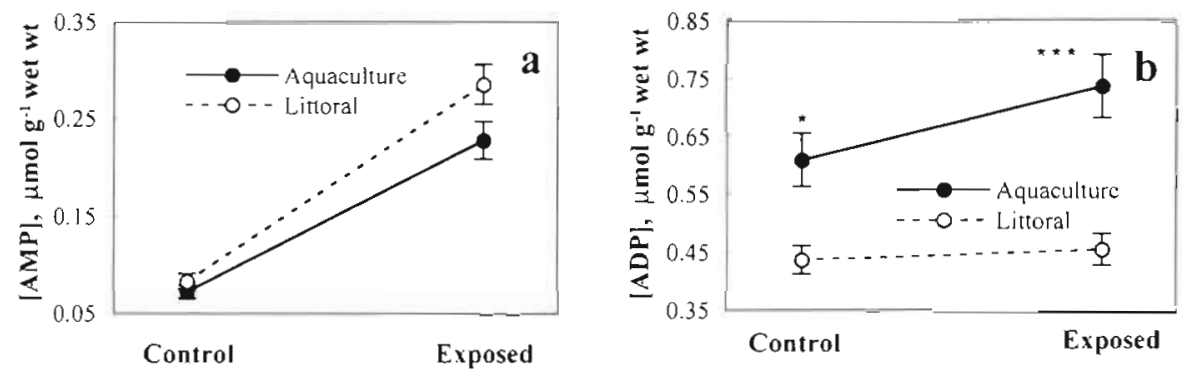

Fig. 3. Changes in the concentrations of (a) AMP, (b) ADP, (c) ATP, and (d) total adenylates in cultured and littoral mussels during air exposure. For further information see Fig. 1
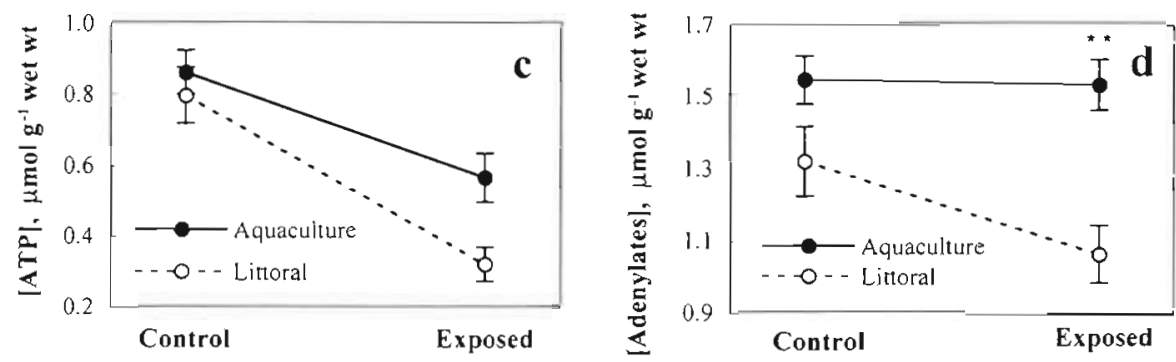

concentrations in control groups did not differ (Fig. 2b). After exposure a significant (Tukey's HSD, $p<0.001$ ) excess of LA levels in cultured mussels over that of littoral ones was observed (Fig 2b). The sum of PLA and LA remained unchanged in both groups. However, the difference in this parameter between mussels from the 2 habitats was highly significant (Tukey's HSD, p < 0.001) (Fig. 2c). Cultured specimens contained 1.6 times more phosphagen/aphosphagen than littoral ones, largely due to the difference in PLA levels under control conditions.

The $R_{P L A}$ was 0.60 in cultured and 0.41 in littoral mussels under control conditions. This difference was significant at $\mathrm{p}<0.001$ (Tukey's HSD). After emersion this parameter declined in both mussel groups to very similar values ranging between 0.14 and 0.17 (Fig. 2d).

\section{Adenylates and ATP turnover rate}

The factor air exposure significantly affected AMP and ATP concentrations as well as the indices AEC and $[A D P] /[A T P]$. The total amount of adenylates did not change in cultured mussels and slightly decreased in littoral specimens.

AMP concentrations in control groups ranged between 0.07 and $0.08 \mu \mathrm{mol} \mathrm{g} \mathrm{g}^{-1}$ wet wt and displayed a more than 3 -fold increase during air exposure (Fig. 3a). AMP levels were similar in mussels from both habitats under all experimental conditions (Tukey's HSD test). However, cultured mussels had slightly lower AMP levels. Free AMP concentrations calculated for control mussels were about 3 and $8 \times 10^{-4} \mu \mathrm{mol} \mathrm{g}^{-1}$ wet wt in cultured and littoral mussels, respectively. The relative rise in free AMP levels after air exposure was much higher than observed for total AMP concentrations (Fig. 4a). In cultured mussels the levels of free AMP increased 29 times while littoral ones showed a 5 -fold rise.

ANOVA showed a statistical difference $(p<0.001)$ in ADP levels between littoral and cultured specimens. Cultured mussels contained 1.5 times more ADP than littoral ones (Fig, 3b). There was no pronounced effect of air exposure on ADP, but in littoral mussels it remained at nearly the same level while it increased in cultured mussels. In contrast, free ADP levels increased significantly $(p<0.001)$. The initial free ADP content was nearly 2 times lower in cultured mussels. However, after a 5 -fold rise during air exposure, free ADP levels in cultured specimens exceeded the concentration in littoral ones (Fig. 4b).

According to 2-way ANOVA, ATP concentration in mussels was influenced by both factors - exposure $(\mathrm{p}<$ $0.001)$ and habitat $(p<0.05)$. The average initial ATP content of the whole body was 0.8 to $0.9 \mu \mathrm{mol} \mathrm{g}{ }^{-1}$ wet $w t$, with slightly lower levels in littoral specimens. Air exposure led to a significant drop in ATP levels, 1.5 $(p<0.05)$ and $2.5(p<0.001)$ times below the control values in cultured and littoral specimens, respectively. The decrease in ATP levels during emersion was more pronounced in littoral mussels (Fig. 3c).

The total amount of adenylates in White Sea mussels ranged between 1.3 and $1.5 \mu \mathrm{mol} \mathrm{g}^{-1}$ wet wt. It was significantly (ANOVA, $p<0.001$ ) higher in cultured mussels. The decrease in ATP content in cultured animals during air exposure was completely compensated by the corresponding rise in ADP and AMP levels; thus, the sum of adenylate levels remained constant 

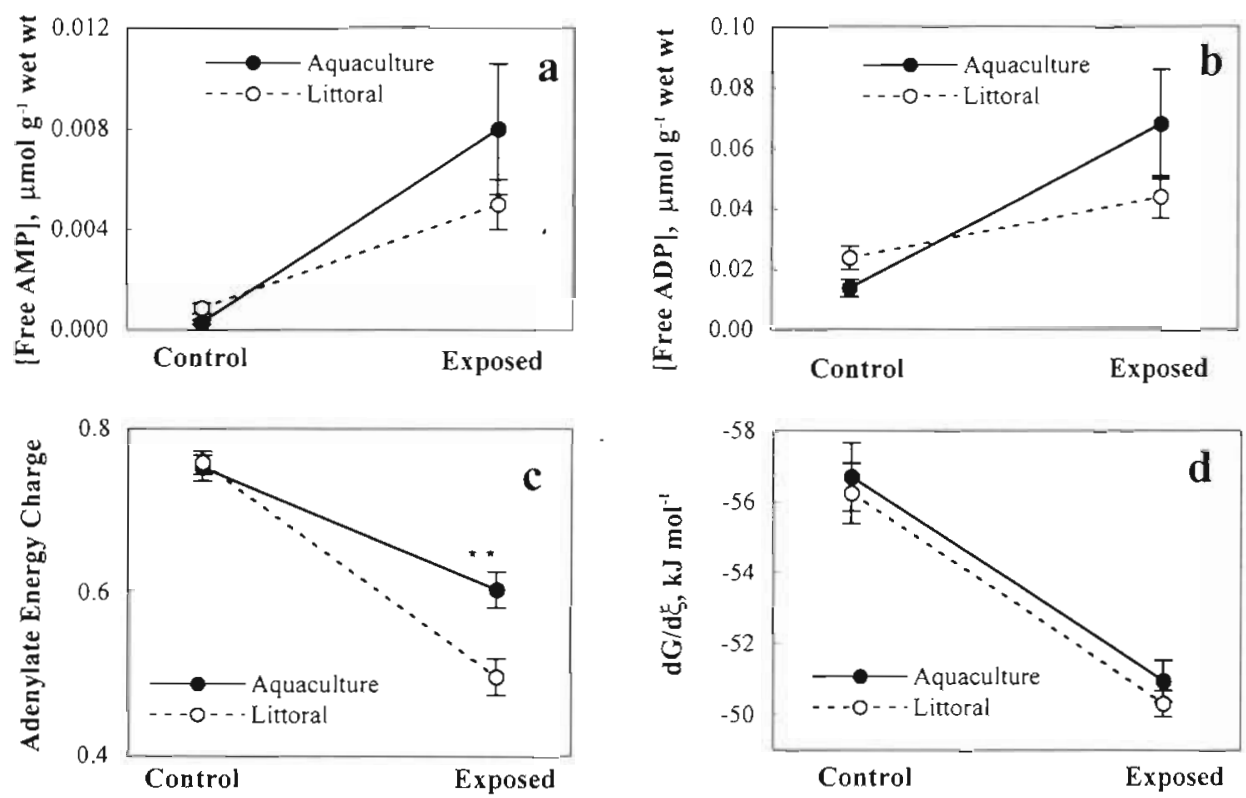

Fig. 4. Changes in the concentrations of free (a) AMP, (b) free ADP, as well as in (c) adenylate energy charge, and (d) the Gibb's free energy change of ATP hydrolysis in cultured and littoral mussels during air exposure. For further information see Fig. 1

(Fig. 3d). In littoral mussels the decrease in ATP was larger, ADP remained unchanged and the rise in AMP levels was also not sufficient to counterbalance the drop in ATP, therefore the adenylate pool decreased (Fig. 3d). The index [ADP]/[ATP] was significantly affected by exposure and increased in emersed mussels. This ratio was similar in mussels from both habitats.

$\mathrm{AEC}$ in mussels under normal conditions was about 0.75 in both groups. After exposure a significant (ANOVA, p < 0.001) drop in AEC by 0.15 and 0.26 was recorded in cultured and littoral mussels, respectively (Fig. 4c). Thus, AEC in exposed mussels differed markedly between the investigated habitats.

Starting from -56 to $-57 \mathrm{~kJ} \mathrm{~mol}^{-1}$ the Gibb's free energy change of ATP hydrolysis, i.e. the driving force for all ATPases, fell in exposed mussels to a value of around $-50 \mathrm{~kJ} \mathrm{~mol}^{-1}$ (Fig. 4d). This change was statistically significant at $p<0.001$. There was no considerable difference in $\mathrm{dG} / \mathrm{d} \xi$ between cultured and littoral mussels.

Using the data on ATP breakdown and PLA degradation during $60 \mathrm{~h}$ of air exposure and assuming that succinate was the only end product during anaerobiosis, it is possible to estimate the metabolic rate in mussels during emersion in terms of ATP turnover rate according to the formula:

$$
\dot{M}_{\text {ATP }}=\frac{-\Delta[\text { ATP }]-\Delta[\text { PLA }]+2.75 \Delta[\text { Succinate }]}{t}
$$

where $\dot{M}_{\text {ATP }}$ is the ATP turnover rate ( $\mu$ mol ATP $g^{-1}$ wet wt $\mathrm{h}^{-1}$ ) and $t$ is the time of air exposure (h). Thus $\dot{M}_{\text {ATP }}$ for cultured mussels during $2.5 \mathrm{~d}$ of anaerobiosis was 0.19 and, for littoral ones, $0.25 \mu \mathrm{mol} \mathrm{ATP} \mathrm{g}^{-1}$ wet wt $\mathrm{h}^{-1}$. In spite of less ATP decrease, the contribution of
PLA depletion was almost 2 times higher in cultured mussels due to a considerable excess in initial PLA concentration and a larger rise in free ADP levels (Table 1). However, the rise in succinate levels caused $\dot{M}_{\text {ATP }}$ to be higher in littoral specimens.

\section{Proton balance}

Sixty hours of environmental anaerobiosis in Mytilus edulis led to the metabolic production of about 5 and $10 \mu \mathrm{mol} \mathrm{H} \mathrm{H}^{+} \mathrm{g}^{-1}$ wet wt in cultured and littoral mussels, respectively (Table 2). $\Delta \mathrm{H}^{+}$met was determined to a major extent by succinate accumulation. Proton buffering by inorganic phosphate through PLA breakdown was higher in cultured mussels. However, impact of this process was negligible in both groups of mussels. Non-respiratory proton load appeared to be low compared to $\Delta \mathrm{H}^{+}{ }_{\text {met }}$ (Table 2). The discrepancy between $\Delta \mathrm{H}^{+}$met and $\Delta \mathrm{H}^{+}$non-resp was $3 \mu \mathrm{mol} \mathrm{g}{ }^{-1}$ wet wt in cultured mussels and reached $9 \mu \mathrm{mol} \mathrm{g}^{-1}$ wet wt in littoral mussels.

\section{DISCUSSION}

Mussels Mytilus edulis are known as facultative anaerobes well adapted to withstand prolonged periods of severe hypoxia or anoxia (for review see de Zwaan \& Mathieu 1992). Mussels experience these conditions in the intertidal zone when exposed to air for hours. Moreover, spring ice and snow melting causes a drastic drop to nearly $0 \%$ salinity in surface seawater layers in some regions of the White Sea 
Table 1. Calculated values of ATP turnover $\left(\dot{M}_{A T P} \mu\right.$ mol ATP $\mathrm{g}^{-1}$ wet $\left.\mathrm{wt} \mathrm{h}^{-1}\right)$ in mussels from the 2 habitats, derived from succinate accumulation (Catabolism), as well as PLA and ATP depletion

\begin{tabular}{|c|c|c|c|c|c|c|c|c|}
\hline \multirow[t]{2}{*}{ Habitat } & \multicolumn{2}{|c|}{ Catabolism } & \multicolumn{2}{|l|}{ PLA } & \multicolumn{2}{|l|}{ ATP } & \multirow{2}{*}{$\begin{array}{l}\text { Sum } \\
\text { ATP equivalents }\end{array}$} & \multirow{2}{*}{$\dot{M}_{\mathrm{ATP}}$} \\
\hline & ATP equivalents & $\%$ & ATP equivalents & $\%$ & ATP equivalents & $\%$ & & \\
\hline Cultured & 8.19 & 71 & 3.07 & 26 & 0.30 & 3 & 11.56 & 0.19 \\
\hline Littoral & 13.33 & 88 & 1.28 & 9 & 0.48 & 3 & 15.09 & 0.25 \\
\hline
\end{tabular}

Table 2. Proton balance ( $\mu \mathrm{mol} \mathrm{g} \mathrm{g}^{-1}$ wet $w \mathrm{t}$ ) in air exposed mussels from different habitats. The analysis is based on differences in metabolite concentrations $\Delta$ Conc (see 'Results')

\begin{tabular}{|c|c|c|c|c|}
\hline & Control & Exposed & $\Delta$ Conc & $\Delta \mathrm{H}_{\text {met }}^{+}$ \\
\hline \multicolumn{5}{|l|}{ Aquaculture } \\
\hline Succinate & 0.23 & 3.51 & 3.28 & 6.56 \\
\hline ATP & 0.86 & 0.57 & -0.31 & - \\
\hline PLA & 4.33 & 1.26 & -3.07 & 1.65 \\
\hline Total $\Delta \mathrm{H}^{+}$met & & & & 4.91 \\
\hline$\Delta \mathrm{H}^{+}$non-resp & & & & 1.87 \\
\hline \multicolumn{5}{|l|}{ Littoral } \\
\hline Succinate & 0.44 & 5.78 & 5.33 & 10.66 \\
\hline ATP & 0.8 & 0.32 & -0.48 & - \\
\hline PLA & 1.85 & 0.57 & -1.28 & 0.71 \\
\hline Total $\Delta \mathrm{H}^{*}$ met & & & & 9.95 \\
\hline$\Delta \mathrm{H}^{+}$non-resp & & & & 1.05 \\
\hline
\end{tabular}

(Babkov \& Lukanin 1985). Such low salinity values can be recorded for 2 wk. They are below the known tolerance limits of mussels (Berger 1986). Low salinity causes a decline in hemolymph osmolality in mussels (Stickle \& Denoux 1976), an increase in respiration rate (Stickle \& Sabourin 1979), and in extreme cases shell closure and survival by use of anaerobic metabolism. Under the conditions of our experiment the period during which mussels can survive without water depends on factors such as temperature and humidity of the surrounding air, the possibility of intermittent gaping, and the reproductive stage of the mussels. White Sea blue mussels survive in air at $+10^{\circ} \mathrm{C}$ for more than $10 \mathrm{~d}$ (Alyakrinskaya 1972, Golikov \& Smirnova 1974). In our experiment the exposure period of $2.5 \mathrm{~d}$ was environmentally realistic, long enough to determine the onset and degree of anaerobiosis, but not critical for survival. No mortality was observed in either control or exposed groups of mussels.

\section{End products}

Under environmental hypoxia various end products are reported to be accumulated in tissues of mussels Mytilus edulis. Predominant are succinate, propionate and acetate (Kluytmans et al. 1977, Widdows et al.
1979, Kluytmans \& Zandee 1983, Demers \& Guderley 1994, and many others), and to a minor extent the opines alanopine (Kreutzer et al. 1989, Demers \& Guderley 1994) and strombine (de Zwaan et al. 1983 , Kreutzer et al. 1989, Demers \& Guderley 1994). In our study only succinate was detected as an anaerobic end product in the White Sea mussels. In support of our findings, Isani et al. (1995) could detect opines only after $14 \mathrm{~d}$ of anoxia at $+10^{\circ} \mathrm{C}$ in $\mathrm{M}$. galloprovincialis.

There are 2 possible explanations of the absence of propionate observed in the present study after $60 \mathrm{~h}$ of air exposure at $+10^{\circ} \mathrm{C}$. Firstly, the typical lag period of propionate formation (Kluytmans et al. 1977, de Zwaan et al. 1982) should be longer than $1 \mathrm{~d}$ at $+10^{\circ} \mathrm{C}$ in coldadapted mussels from the White Sea. Widdows et al. (1979) did not detect propionate accumulation in Mytilus edulis during $48 \mathrm{~h}$ air exposure at $+10^{\circ} \mathrm{C}$, while at $+20^{\circ} \mathrm{C}$ propionate concentration increased several fold. An alternative explanation could be derived from the fact that the conversion of succinate to propionate in mussels shows strong seasonal fluctuations. For mussels from the North Sea it was shown that propionate synthesis was high in summer and nearly absent in winter (Kluytmans et al. 1980). Mussels for our work were collected in late September and the experiment was performed in mid-October. Possibly, propionate (and acetate) were not accumulated due to seasonal metabolic changes.

The extent of succinate accumulation is in close agreement with previously published data for Mytilus edulis under similar experimental conditions (Kluytmans et al. 1975, Ebberink et al. 1979, Widdows et al. 1979, Kluytmans \& Zandee 1983).

\section{$\mathrm{pH}_{\mathrm{i}}$ and proton balance}

$\mathrm{pH}_{1}$ of White Sea Mytilus edulis obtained in the present study appeared to be lower than those known from the literature. In our experiment $\mathrm{pH}_{1}$ in control groups never exceeded 6.96. Differences among tissues cannot be held responsible because we also determined $\mathrm{pH}_{\mathrm{i}}$ in each muscle, mantle and hepatopancreas tissues and did not record $\mathrm{pH}_{1}$ values above 7.02 (data not presented). $\mathrm{pH}_{1}$ values measured by the distribution of 
$\left[{ }^{14} \mathrm{C}\right] \mathrm{DMO}$ for muscle tissues and for the whole body of $M$. edulis from the Canadian Atlantic coast were 7.37 and 7.38, respectively (Walsh et al. 1984). $\mathrm{pH}_{\mathrm{i}}$ determined by both DMO distribution and by $1^{31} \mathrm{P} / \mathrm{NMR}$ spectroscopy in resting muscle of mussels from The Netherlands ranged between 7.41 and 7.44 (Zange et al. 1990). Other data available for $M$. edulis concerned $\mathrm{pH}$ in other tissues (and body fluids): foot, 7.42 ; mantle, 7.14 (Walsh et al. 1984); haemolymph, 7.4 to 7.6 (Jokumsen \& Fyhn 1982, de Zwaan et al. 1983, Walsh et al. 1984); extrapallial fluid, 7.3 to 7.6 (Wijsman 1975).

However, the data obtained in the present study do not seem unrealistic. Intracellular $\mathrm{pH}$ in unfertilized eggs of sea urchins is 6.8 (Hamaguchi et al. 1997); in the whole body of water scorpion Ranatra chinensis (Insecta) a value of 6.84 was found (Chiba et al. 1991). Both studies were performed using the $\left[{ }^{31} \mathrm{P}\right] \mathrm{NMR}$ method. Mean $\mathrm{pH}$ value in the foot tissue of mussels, measured by a glass electrode pricked directly into the foot, was about 6.95 (Wijsman 1975). The explanation of low $\mathrm{pH}_{1}$ values obtained in the present study may therefore be derived from the differences in methods. We used the homogenate technique for $\mathrm{pH}_{\mathrm{i}}$ determinations. Usually, homogenate and DMO distribution techniques yield similar values in white muscles of several species, while in tissues containing large numbers of mitochondria (e.g. in heart muscle), DMO considerably overestimates mean $\mathrm{pH}_{\mathrm{i}}$ (Pörtner et al. 1990). In this context, it should be noted that $\mathrm{pH}_{\mathrm{i}}$ in the muscle tissues of lugworms Arenicola marina from the subarctic White Sea was lower than in lugworms from the temperate North Sea (Sommer et al. 1997). The difference is explained by higher mitochondrial densities in the tissues of cold-adapted White Sea lugworms. Accordingly, lower $\mathrm{pH}_{\mathrm{i}}$ values are also found in abdominal muscle of the sand shrimp Crangon crangon from the White Sea compared to specimens from the North Sea (Sartoris \& Pörtner 1997). We conclude that at least some of the $\mathrm{pH}$ difference between literature values and our data is due to the higher content of mitochondria in White Sea mussels. Even if other, acidic cell compartments should contribute to the low pH monitored by the homogenate technique this should not affect our conclusion concerning the difference between littoral and cultured mussels and their $\mathrm{pH}$ changes.

Intracellular $\mathrm{pH}$ is considered to be one of the important factors controlling metabolic rate for review see Pörtner 1993) as well as the pathways of metabolic energy production in invertebrates during sustained anaerobiosis (Wijsman 1975, Kluytmans et al. 1977. Grieshaber et al. 1994). In a simplified approach, $\mathrm{pH}_{1}$ changes depend upon the metabolites formed and the extent of PLA degradation as well as the substrates used for energy production (Pörtner 1987a) and tissue buffer capacity (Heisler 1986). They also depend upon the possibility to release the protonated end products into the external medium. In bivalves, this depends on 'gaping' patterns (Wijsman 1975, Littlewood \& Young 1994). Moreover, the neutralisation of acidic substances by calcium carbonates from the shell determines the extent of $\mathrm{pH}_{1}$ changes (Alyakrinskaya 1972, Akberali et al. 1977, Jokumsen \& Fyhn 1982). We found a small (less than $0.1 \mathrm{pH}$ unit) but statistically highly significant (ANOVA, $p<0.001$ ) acidification in White Sea mussel tissues indicating the onset of anaerobic metabolism. Minimal $\mathrm{pH}_{1}$ was 6.65. For comparison, $\mathrm{pH}$ in the foot of Mytilus edulis rapidly decreased from 6.95 to 6.65 during the first 5 h of air exposure and then within 7 d reached a value of about 6.5 (Wijsman 1975). Eight hours of air exposure led to a fall of $\mathrm{pH}_{\mathrm{i}}$ by about 0.35 units in the whole body of mussels and by nearly 0.9 units in the mantle tissue, reaching a low value of 6.27 (Waish et al. 1984).

A significant difference in $\mathrm{pH}_{\mathrm{i}}$ was recorded for mussels from the 2 habitats. Cultured mussels were characterised by higher $\mathrm{pH}_{\mathrm{i}}$ values than littoral ones in both control and exposed groups. This goes along with a larger degree of succinate accumulation and of net ATP depletion in littoral mussels (Figs. 1 b \& 3c) leading to acidosis. We interpret the lower $\mathrm{pH}_{1}$ and higher rate of succinate accumulation to indicate higher mitochondrial content in littoral mussels, similar to findings in Arenicola marina (Sommer et al. 1997, Sommer \& Pörtner 1999).

Cultured mussels initially had a much higher PLA content and demonstrated more substantial PLA degradation during exposure than littoral ones (Fig. 2a). Since it was previously shown (Pörtner 1987a,b) that PLA breakdown is accompanied by proton absorption, it could be expected that cultured mussels were able to maintain higher $\mathrm{pH}_{1}$ values. The accumulation of $P_{i}$, which in turn can increase tissue buffer capacity, was also more pronounced in cultured mussels (Fig. 1c). In the context of the findings that cultured mussels showed less succinate accumulation during anaerobiosis than littoral mussels (Table 1), it appears that anaerobic ATP production was shifted in cultured mussels from proton producing catabolism to proton consuming depletion of PLA reserves. This feature together with lower PLA levels would also support the conclusion that littoral mussels possessed more mitochondria.

The non-respiratory proton load in mussels was 1 to $2 \mu \mathrm{mol} \mathrm{g}^{-1}$ wet wt which is much lower than values found for lugworms Arenicola marina (Sommer \& Pörtner 1999) or periwinkles Littorina spp. (I. M. Sokolova, C. Bock \& H.-O. Pörtner unpubl.). Succinate production was the major source of protons. These data corresponded well to those obtained in Littorina spp. (Sokolova et al. unpubl.). In contrast, opine production 
was the most important source of protons in A. marina (Sommer \& Pörtner 1999). Metabolic proton formation was 2 times higher in littoral mussels supporting our conclusion that littoral mussels show lower $\mathrm{pH}_{\mathrm{i}}$ values at higher ATP turnover rate than cultured ones. The significant excess of $\Delta \mathrm{H}^{+}$mot over $\Delta \mathrm{H}^{+}$non-resp indicates efficient $\mathrm{pH}_{\mathrm{i}}$ regulation either by proton release from cells during anaerobiosis (Pörtner et al. 1991) or by contribution of calcium carbonate buffers from the shells (Akberali et al. 1977, Byrne \& McMahon 1991).

\section{High-energy phosphates and metabolic rate}

Absolute values of PLA contents in White Sea Mytilus edulis are in good agreement with those published in the literature (Beis \& Newsholme 1975, Ebberink et al. 1979, de Zwaan et al. 1982). Rpla was, however, lower than previously reported (Zange et al. 1989, Isani et al. 1995). Thus, for the resting anterior byssus retractor muscle of $M$. edulis, $\mathrm{R}_{\mathrm{PLA}}$ in normoxia was not less than 0.8 (Zange et al. 1989), while mean values for cultured White Sea mussels were 0.60 and 0.41 for littoral ones. In this context, it should be noted that all literature data concern muscle tissues, while we used the whole mussel. Isani et al. (1995) reported $0.21 \mu \mathrm{mol} \mathrm{g} \mathrm{g}^{-1}$ wet wt of PLA under normal conditions for the whole body in $M$. galloprovincialis, a value much lower than our data. The authors explained this phenomenon by the spawning period at the time of the experiments. Seasonal variations of the PLA pool in mussels were reported elsewhere (Ebberink et al. 1979, Zurburg \& Ebberink 1981) and may be correlated with fluctuations in aerobic metabolic rate and in the setpoints of $\mathrm{pH}_{\mathrm{j}}$ regulation. Possibly, the frequent oscillation between net PLA depletion and rephosphorylation of LA in littoral specimens may also lead to lower steady state levels of PLA and LA.

Maximal ATP levels are observed in muscles and gonads, while gills and hepatopancreas contain much less ATP (Zurburg \& Ebberink 1981, Goromosova \& Shapiro 1984). In White Sea mussels ATP concentration in the whole body ranged between 0.80 and $0.86 \mu \mathrm{mol} \mathrm{g}{ }^{-1}$ wet wt. This is about 2 times lower than the values published for the whole body of Mytilus edulis from the North Atlantic and the North Sea (Addink \& Veenhof 1975, Wijsman 1976, Ansell 1977), but close to or even higher than those recorded for other species: M. galloprovincialis (Isani et al. 1995), gastropods Patella caerulea (Michaelidis \& Beis 1990) and Hexaplex trunculus (Xomali et al. 1996). Possibly, the lower adenylate levels are related to lower mean temperatures at the White Sea (Zielinski \& Pörtner 1996). AEC in White Sea $M$. edulis did not differ between habitats and was about 0.75 . This value is in close agreement with those known for marine molluscs (Beis \& Newsholme 1975, de Zwaan et al. 1982, Kapper \& Stickle 1987, Isani et al. 1995). Air exposure for $60 \mathrm{~h}$ caused a highly significant decline in ATP and a correspondent increase in AMP concentrations in mussels from both habitats. The ATP and AEC decrease in littoral mussels was more pronounced as reflected in their higher metabolic rate (Figs. $3 c \& 4 c$ ). PLA and ATP breakdown goes along with an increase of free AMP and ADP contents which appeared to be more pronounced in cultured mussels. Under normal conditions free AMP and ADP concentrations in mussels were found to be somewhat lower than those published for Sipunculus nudus (Zielinski \& Pörtner 1996). Values of the Gibb's free energy changes of ATP hydrolysis were in good agreement with those recently published for some other species: $-57 \mathrm{~kJ} \mathrm{~mol}^{-1}$ for resting muscle of squid (Pörtner et al. 1996), and $-56 \mathrm{~kJ}$ $\mathrm{mol}^{-1}$ for a sipunculid worm (Zielinski \& Pörtner 1996), and for Littorina spp. (Sokolova et al. unpubl.). The observed drop in $\mathrm{dG} / \mathrm{d} \xi$ after $60 \mathrm{~h}$ of air exposure at $+10^{\circ} \mathrm{C}$ indicates a considerable decrease of cellular energy levels. However, the value of $-50 \mathrm{~kJ} \mathrm{~mol}^{-1}$ should be above the level critical for survival since $M$. edulis is known to withstand longer periods of anaerobiosis at this temperature. The values of $\mathrm{dG} / \mathrm{d} \xi$ after air exposure in Mytilus from the White Sea coincide with those obtained for muscle tissue of an Antarctic bivalve mollusc, Limopsis marionensis, and of squid in normal conditions (Pörtner et al. 1999)

The observed difference in ATP depletion between mussels from the 2 habitats together with the difference in succinate accumulation gives evidence that cultured mussels were capable of a more efficient metabolic arrest, reducing their glycolytic flux to a greater extent than littoral ones. Indeed, the ATP turnover rate (Table 1) was 1.3 times higher in littoral than in cultured specimens. Our values of $\dot{M}_{\text {ATp agree }}$ with data estimated for Mytilus galloprovincialis during $24 \mathrm{~h}$ exposure in anoxic water at $+10^{\circ} \mathrm{C}$ (Isani et al. $1995)$ and significantly exceed those for North Sea $M$. edulis at $+20^{\circ} \mathrm{C}$ (de Zwaan et al. 1991). By contrast, the bivalve mollusc Scapharca inaequivalvis displayed a 10 times lower anaerobic metabolic rate than $M$. galloprovincialis, suggesting a higher resistance to hypoxia (Isani et al. 1989, de Zwaan et al. 1991)

Published data concerning the difference in metabolic rate in subtidal and intertidal mussels are controversial. Shick et al. (1986) determined heat dissipation in mussels as a measure of metabolic rate and received results close to those obtained in the present study. They reported that intertidal Mytilus edulis had greater total heat dissipation during exposure and subsequent recovery than subtidal ones. Aerobic metabolic rate and 'oxygen debt' after air exposure of $M$. 
californianus from 2 vertically separated populations were also higher in mussels inhabiting upper horizons of the intertidal zone, compared to those living at lower levels (Moon \& Pritchard 1970). These results go along with data reported by de Vooys (1979) that long-term intertidal acclimatisation leads to higher rates of succinate production, and therefore metabolic rate in $M$. galloprovincialis. In contrast, de Vooys \& de Zwaan (1978) recorded a more pronounced oxygen debt after air exposure in subtidal compared to intertidal $M$. edulis, which might suggest a higher anaerobic metabolic rate in subtidal mussels. Demers \& Guderley (1994) wrote that wild intertidal $M$. edulis were characterised by lower anaerobic metabolic flux, if compared to cultured specimens. The authors found that intertidal acclimatisation reduced anaerobic succinate accumulation. The rate of anaerobic ATP production also decreased by at least 50\%. Possibly, the gaping behaviour of intertidal mussels reduces anaerobiosis, an influence excluded in our study. Animals adapted to environmental anaerobiosis (intertidal conditions) are expected to (1) maintain high reserves of glycogen, (2) possess mechanisms to minimise metabolic acidosis, (3) use more efficient pathways of fermentative ATP production, and (4) reduce metabolic rate to a greater extent (Storey \& Storey 1990). This may only hold true for between species comparisons. Mitochondrial content may rise when temperature fluctuations rise as is the case for White Sea intertidal mussels. This certainly depends upon the intertidal area investigated in a latitudinal gradient. In support of this hypothesis an elevated mitochondrial density in cold-adapted eurythermal animals is suggested to induce a rise in metabolic cost owing to the cost of mitochondrial maintenance (Pörtner et al. 1998). Mitochondrial density is higher in White Sea than in North Sea Arenicola marina, and associated with a more than 2-fold rise in standard metabolic rate (Sommer \& Pörtner 1999). The present data suggest that a high amplitude of temperature fluctuations may exacerbate the rise in energy expenditure owing to a further increase in mitochondrial density. This leads to higher aerobic and anaerobic metabolic rates in littoral compared to cultured $M$. edulis and would also explain reduced growth rates in intertidal specimens.

\section{Conclusions}

Mussels from the intertidal zone demonstrate lower abilities for metabolic depression under air exposure than cultured (sublittoral) ones. Cultured mussels are characterised by a higher initial PLA content. These differences may reflect the difference in mitochondrial density depending on the habitat.
Acknowledgements. A.A.S. is grateful to the Alfred Wegener Institute for Polar and Marine Research (Bremerhaven, Germany) for supporting his work as a guest scientist in 1996, 1997 and 1998, and to Dr Inna Sokolova, Dr Angela Sommer and Mr Timo Hirse for considerable help during the experimental work. Alfred Wegener Institute publication no. 1594

\section{LITERATURE CITED}

Addink ADF, Veenhof PR (1975) Regulation of mitochondrial matrix enzymes in Mytilus edulis L. In: Barnes $\mathrm{H}$ (ed) Proc 9th Eur Mar Biol Symp. Aberdeen University Press. Aberdeen, p 109-1.19

Akberali HB, Mariott KRM, Trueman ER (1977) Calcium utilisation during anaerobiosis induced by osmotic shock in a bivalve mollusc. Nature 266:852-853

Alyakrinskaya IO (1972) Biochemical adaptations of water molluscs to air exposure. Zool Zh 51(11):1630-1636 in Russian)

Ansell AD (1977) The adenosine triphosphate content of some marine bivalve molluscs. J Exp Mar Biol Ecol 28:269-283

Atkinson DF (1968) The energy charge of the adenylate pool as a regulatory parameter. Interaction with feedback modifiers. Biochemistry 7:4030-4034

Babkov AI (1982) A short hydrological characteristic of Chupa Inlet in the White Sea. In: Kulakowski EE (ed) Ecological investigations of species perspective for aquaculture in the White Sea. Zoological Institute, Leningrad, p 94-98 (in Russian)

Babkov AI, Lukanin VV (1985) Spring changes of salinity and temperature in surface levels of the White Sea and their influence on distribution of organisms inhabiting intertidal and upper subtidal zones. In: Skarlato OA (ed) Biocenoses of Chupa Inlet and their seasonal dynamics, Vol 27(35). Nauka, Leningrad p 3-16 (in Russian)

Baird RH (1966) Factors affecting the growth and condition of mussels (Mytilus edulis L.). Fish Invest Ser II 25, 2: 33 pp

Beis I, Newsholme E (1975) The contents of adenine nucleotides, phosphagens and some glycolytic intermediates in resting muscles from vertebrates and invertebrates. Biochem J 152:23-32

Berger VJa (1986) Adaptations of marine molluscs to environmental salinity changes. Nauka, Leningrad (in Russian)

Byrne RA, McMahon BR (1991) Acid-base and ionic regulation., during and following emersion, in the freshwater bivalve, Anodonta grandis simpsoniana (Bivalvid: Unionidae). Biol BuII 181:289-297

Chiba A, Hamaguchi M, Tokuno I, Asai T, Okuda $H_{\text {, }}$ Chichibu $S$ (1991) Changes in high-energy phosphate metabolism in the water scorpion, Ranatra chinensis, under cold water-warm water stress. Comp Biochem Physiol 100A:399-405

Coleman N (1973) The oxygen consumption of Mytilus edulis in air. Comp Biochem Physiol 45A(2):393-402

Demers A, Guderley $H(1994)$ Acclimatisation to intertidal conditions modifies the physiological response to prolonged air exposure in Mytilus edulis. Mar Biol 118: $115-122$

de Vooys CGN (1979) Anaerobic metabolism in sublittoral living Mytilus galloprovincialis in the Mediterranean. I. Partial adaptation of anaerobic energy metabolism. Neth J Sea Res 13(2): 192-202

de Vooys CGN, de Zwaan A (1978) The rate of oxygen consumption and ammonia excretion by Mytilus edulis after various periods of exposure to air. Comp Biochem Physiol $60 \mathrm{~A}(3): 343-347$ 
de Zwaan A, Mathieu M (1992) Cellular biochemistry and endocrinology. In: Gosling $E$ (ed) The mussel Mytilus. Ecology, physiology, genetics and culture. Dev Aquacult Fish Sci 25:223-307

de Zwaan A, de Bont AMT, Verhoeven A (1982) Anaerobic energy metabolism in isolated adductor muscle of the sea mussel Mytilus edulis L. J Comp Physiol 149B:137-143

de Zwaan A, de Bont AMT, Zurburg W, Bayne BL, Livingstone DL (1983) On the role of strombine formation in the energy metabolism of adductor muscle of a sessile bivalve.

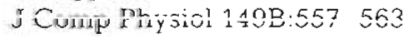

de Zwaan A, Cortesi P, van den Thillart G, Roos J, Storey KB (1991) Differential sensitivities to hypoxia-tolerant marine molluscs: a biochemical analysis. Mar Biol 111(3):343-351

Dickie LM, Boudreaup PR, Freeman KR (1984) Influences of stock and site on growth and mortality in the blue mussel (Mytilus edulis). Can J Fish Aquat Sci 41(1):134-140

Ebberink RHM, Zurburg W, Zandee DI (1979) The energy demand of the posterior adductor muscle of Mytilus edulis in catch during exposure to air. Mar Biol Lett 1:23-31

Eberlee JC, Storey KB (1984) Buffering capacities of the tissues of marine molluscs. Physiol Zool 57:567-572

Fischer JH (1995) Specific detection of nucleotides, creatine phosphate, and their derivatives from tissue samples in a simple, isocratic, recycling, low volume system. In: Fischer JH (ed) LC-GC Int. 8, p 254-262

Glotov NV, Zhivotowski LA, Hovanov NV, Khromov-Borisov NN (1982) Biometry. Leningrad University, Leningrad (in Russian)

Golikov AN, Smirnova NF (1974) Resistance of some gastropod and bivalve species from Chupa Inlet (White Sea) to extreme influences in relation to the problem of evolution of resistance. In: Bykhovsky BE (ed) Seasonal phenomena in the life of White and Barents Seas. Nauka, Leningrad, p 307-319

Goromosova SA, Shapiro AZ (1984) The main biochemical patterns of energy metabolism in mussels. Legkaya i Pishchevaya Promyshlennost, Moscow (in Russian)

Grieshaber MK, Kronig E, Koormann R (1978) A photometric estimation of phospho-L-arginine, arginine and octopine using homogeneous octopine dehydrogenase isozyme 2 from the squid, Loligo vulgaris Lam. Hoppe-Seyler's Z Physiol Chem 359:133-136

Grieshaber MK, Hardewig I, Kreutzer U, Pörtner HO (1994) Physiological and metabolic responses to hypoxia in invertebrates. Rev Physiol Biochem Pharmacol 125:43-147

Hamaguchi MS, Watanabe K, Hamaguchi Y (1997) Regulation of intracellular $\mathrm{pH}$ in sea urchin eggs by medium containing both weak acid and base. Cell Struct Funct 22: $387-398$

Hardewig I, Addink ADF, Grieshaber MK, Pörtner HO, van den Thillart C (1991) Metabolic rates at different oxygen levels determined by direct and indirect calorimetry in the oxyconformer Sipunculus nudus. J Exp Biol 157:143-160

Hejsler N (1986) Buffering and transmembrane ion transfer processes. In: Heisler $N$ (ed) Acid-base regulation in animals. Elsevier Science Publisher BV (Biomedical Division), Amsterdam, p 3-47

Holwerda DA, Veenhof PR, de Zwaan A (1984) Physiological and biochemical investigations of the ecological relevance of anaerobiosis in bivalves. I. The changes in activity of mussel adductor muscle and mantle pyruvate kinase during aerial exposure and reimmersion. Mar Biol Lett 5: $185-190$

Isani G, Cattani O, Caprene E, Tacconi S, Cortesi P (1989) Energy metabolism during anaerobiosis and recovery in the posterior adductor muscle of the bivalve Scapharca inaequivalvis (Bruguiere). Comp Biochem Physiol 93B(1): $193-200$

Isani G, Cattani O, Zurzolo M, Pagnucco C, Cortesi P (1995) Energy metabolism of the mussel, Mytilus galloprovincialis, during long-term anoxia. Comp Biochem Physiol 110B:103-113

Jokumsen A, Fyhn HJ (1982) The influence of aerial exposure upon respiratory and osmotic properties of haemolymph for two intertidal mussels, Mytilus edulis L. and Modiolus demissus L. J Exp Mar Biol Ecol 61(2):189-203

Kapper MA, Stickle WB (1987) Metabolic responses of the estuarine gastropod Thais haemastoma to hypoxia. Physiol Zool 60(1):159-173

Kluytmans JH, Zandee DI (1983) Comparative study of the formation and excretion of anaerobic fermentation products in bivalves and gastropods. Comp Biochem Physiol $75 B(4): 729-732$

Kluytmans JH, Veenhof PR, de Zwaan A (1975) Anaerobic production of volatile fatty acids in the sea mussel Mytilus edulis L. J Comp Physiol 104:71-78

Kluytmans JH, de Bont MT, Janus J, Wijsman TCM (1977) Time dependent changes and tissue specificities in the accumulation of anaerobic fermentation products in the sea mussel Mytilus edulis L. Comp Biochem Physiol 58B: $81-87$

Kluytmans JH, Zandee DI, Zurburg W, Pieters H (1980) The influence of seasonal changes on energy metabolism in Mytilus edulis (L.). III. Anaerobic energy metabolism. Comp Biochem Physiol 67B:307-315

Kreutzer U, Siegmund BR, Grieshaber MK (1989) Parameters controlling opine formation during muscular activity and environmental hypoxia. J Comp Physiol 159B:617-628

Labarta U, Fernandez-Reiriz MJ, Babarro JMF (1997) Differences in physiological energetics between intertidal and raft cultivated mussels Mytilus galloprovincialis. Mar Ecol Prog Ser 152:167-173

Littlewood DTJ, Young RE (1994) The effect of air-gaping behaviour on extrapallial fluid $\mathrm{pH}$ in the tropical oyster Crassostrea rhizophorae. Comp Biochem Physiol 107A(1): $1-6$

Mallet AL, Carver CEA, Freeman KR (1990) Summer mortality of the blue mussel in eastern Canada: spatial, temporal, stock and age variation. Mar Ecol Prog Ser 67:35-41

Michaelidis B, Beis I (1990) Studies on the anaerobic energy metabolism in the foot muscle of marine gastropod Patella caerulea (L.). Comp Biochem Physiol 95B:493-500

Moal J, Samain JF, Le Coz JR, Daniel JY (1989) Responses and adaptations of adenylate energy charge and digestive enzyme activities to tidal emersion of Crassostrtea gigas population in Marennes-Oleron Bay. Sci Mar 53: $699-704$

Moon TW, Pritchard AW (1970) Metabolic adaptations in vertically-separated populations of Mytilus californianus J Exp Mar Biol Ecol 5:35-46

Okumus I, Stirling HP (1994) Physiological energetics of cultivated mussels (Mytilus edulis) populations in two Scottish west coast sea lochs. Mar Biol 119:125-131

Pörtner HO (1987a) Contributions of anaerobic metabolism to $\mathrm{pH}$ regulation in animal tissues: theory. J Exp Biol 131: $69-87$

Pörtner HO (1987b) Anaerobic metabolism and changes in acid-base status: quantitative interrelationships and $\mathrm{pH}$ regulation in the marine worm Sipunculus nudus. J Exp Biol 131:89-105

Pörtner HO (1990) Determination of intracellular buffer values after metabolic inhibition by fluoride and nitrilotriacetic acid. Respir Physiol 81:275-288 
Pörtner HO (1993) Multicompartmental analyses of acid-base and metabolic homeostasis during anaerobiosis: invertebrate and lower vertebrate examples. In: Hochachka PW. Lutz PL, Sick T, Rosental M, van den Thillart G (eds) Surviving hypoxia: mechanisms of control and adaptation. CRC Press Inc, Boca Raton FL, p 139-156

Pörtner HO, Boutilier RG, Tang Y. Toews DP (1990) Determination of intracellular $\mathrm{pH}$ and $\mathrm{P}_{\mathrm{CO}_{2}}$ after metabolic inhibition by fluoride and nitrilotriacetic acid. Respir Physiol 81 $255-274$

Pörtner HO, Andersen NA, Heisler N (1991) Proton-equivalent ion transfer in Sipunculus nudus as a function of ambient oxygen tension: relationship with energy metabolism. J Exp Biol 156:21-39

Pörtner HO, Finke E, Lee PG (1996) Metabolic and energy correlates of intracellular $\mathrm{pH}$ in progressive fatigue of squid (L. brevis) mantle muscle. Am J Physiol 271 R1403-R1414

Pörtner HO, Hardewig I, Sartoris FJ, van Di.jk PLM (1998) Energetic aspects of cold adaptation: critical temperatures in metabolic, ionic and acid-base regulation? In: Pörtner HO, Playle RC (eds) Cold ocean physiology. Cambridge University Press, Cambridge, p 88-120

Pörtner HO, Peck L, Zielinski S, Conway LZ (1999) Intracellular $\mathrm{pH}$ and energy metabolism in the highly stenothermal Antarctic bivalve Limopsis marionensis as a function of ambient temperature. Polar. Biol 22:17-30

Rodhouse PG, Roden CM. Hensey MP, Ryan TH (1984) Resource allocation in Mytilus edulis on the shore and in suspended culture. Mar Biol 84:27-34

Sartoris FJ, Pörtner HO (1997) Temperature dependence of ionic and acid-base regulation in boreal and arctic Crangon crangon and Pandalus borealis. J Exp Mar Biol Ecol $211: 69-83$

Seed R (1969) The ecology of Mytilus edulis L. (Lamellibranchiata) on exposed rocky shores. II. Growth and mortality. Oecologia 3:317-350

Seed R, Suchanek TH (1992) Population and community ecology of Mytilus. In: Gosling E (ed) The mussel Mytilus. Ecology, physiology, genetics and culture. Dev Aquacult Fish Sci 25:87-169

Shick JM, Gnaiger E, Widdows J, Bayne BL, de Zwaan A (1986) Activity and metabolism in the mussel Mytilus edulis L. during intertidal hypoxia and aerobic recovery. Physiol Zool 59:627-642

Sommer A, Klein B, Pörtner HO (1997) Temperature induced anaerobiosis in two populations of the polychaete worm Arenicola marina (L.). J Comp Physiol 167B:25-35

Sommer A, Pörtner HO (1999) Exposure of Arenicola marina (L.) to extreme temperatures: adaptive flexibility of a boreal and a subpolar population. Mar Ecol Prog Ser 181. $215-226$

Editorial responsibility: Otto Kinne (Editor),

Oldendort/Luhe, Germany
Stickle WB, Denoux GJ (1976) Effects of in situ tidal salinity fluctuations on osmotic and ionic composition of body fluid in Southeastern Alaska rocky intertidal faund. Mar Biol $37: 125-135$

Stickle WB, Sabourin TD (1979) Effects of salinity on the respiration and heart rate of the common mussel, Mytilus edulis L., and the black chiton, Katherina tunicata (Wood). J Exp Mar Biol Ecol 41:257-268

Storey KB, Storey JM (1990) Metabolic rate depression and biochemical adaptation in anaerobiosis, hibernation and estivation. Q Rev Biol 65:145-174

Sukhotin AA, Maximovich NV (1994) Variability of growth rate in Mytilus edulis L. from the Chupa Inlet (the White Sea). J Exp Mar Biol Ecol 176:15-26

Walsh PJ, McDonald DG, Booth CE (1.984) Acid-balance in the sea mussel, Mytilus edulis. Effects of hypoxia and airexposure on intracellular acid-base status. Mar Biol Lett 5: 359-369

Widdows J, Bayne BL, Livingstone DR, Newell RIE, Donkin P (1979) Physiological and biochemical responses of bivalve molluscs to exposure to air. Comp Biochem Physiol 62A: $301-308$

Wijsman TCM (1975) pH fluctuations in Mytilus edulis L in relation to shell movements under aerobic and anaerobic conditions. In: Barnes H (ed) Proc 9th Eur Mar Biol Symp. Aberdeen University Press, Aberdeen, p 139-149

Wijsman TCM (1976) Adenosine phosphates and energy charge in different tissues of Mytilus edulis L. under aerobic and anaerobic conditions. J Comp Physiol 107B: $129-140$

Wollenberger A, Ristau D, Schoffa G (1960) Eine einfache Technik der extrem schnellen Abkühlung grösserer Gewebestücke. Pflueg Arch 270:399-412

Xomali R, Kaloyaianni M, Beis I (1996) Time course of a tissue specific metabolism of the subtidal gastropod Hexaplex trunculus under anaerobic conditions. Nautilus 110:1-11

Zange J, Pörtner HO, Grieshaber MK (1989) The anaerobic energy metabolism in the anterior byssus retractor muscle of Mytilus edulis during contraction and catch. J Comp Physiol 1598:349-358

Zange J, Grieshaber MK, Jans AWH (1990) The regulation of intracellular $\mathrm{pH}$ estimated by ${ }^{31} \mathrm{P}-\mathrm{NMR}$ spectroscopy in the anterior byssus retractor muscle of Mytilus edulis L. J Exp Biol 150:95-109

Zielinski S, Pörtner HO (1996) Energy metabolism and ATP free energy change of the intertidal worm Sipunculus nudus below a critical temperature. J Comp Physiol 166B: 492-500

Zurburg W, Ebberink RHM (1981) The anaerobic energy demand of Mytilus edulis. Organ specific differences in ATP-supplying processes and metabolic routs. Mol Physiol 1:153-164

Submitted: December 3, 1998; Accepted: March 16, 1999 Proofs received from author(s): July 8, 1999 